\title{
Fenomena Pekerja Miskin dan Faktor-Faktor yang Memengaruhi Persentase Pekerja Miskin di Indonesia Tahun 2015-2018
}

\author{
Ikhsan Margo Pangestu \\ Badan Pusat Statistik, Kabupaten Jeneponto, Sulawesi Selatan, Indonesia \\ *Korespondensi: ikhsanmargo@bps.go.id \\ [diterima: September 2018-revisi: Oktober 2018-diterbitkan daring: Juli 2019]
}

\begin{abstract}
ABSTRAK
Seiring dengan membaiknya angka persentase kemiskinan dan tingkat pengangguran terbuka pada tingkat nasional, masih terdapat pekerjaan rumah yang besar terkait dengan disparitas antar daerah. Pada satu sisi, persebaran angka pengangguran antar provinsi cenderung merata, tetapi disisi lain angka kemiskinan menunjukkan hal sebaliknya yaitu masih banyak provinsi yang memiliki angka kemiskinan cukup tinggi. Kondisi ini memberikan indikasi adanya fenomena pekerja miskin. Penelitian ini bertujuan untuk mempelajari fenomena pekerja miskin serta melihat pengaruh faktor kebijakan dana desa, investasi, dan ketenagakerjaan terhadap pekerja miskin pada tahun 2015-2018. Metode analisis dilakukan dengan analisis deskriptif dan inferensia menggunakan regresi data panel. Hasil penelitian menunjukkan bahwa persebaran angka pekerja miskin menurut provinsi menunjukkan kondisi yang beragam dan cenderung tidak merata dimana masih banyak daerah yang memiliki angka pengangguran rendah tetapi angka pekerja miskinnya cenderung tinggi. Studi ini juga menemukan bahwa program dana desa, persentase pekerja formal, dan tingkat setengah pengangguran berpengaruh signifikan terhadap jumlah pekerja miskin.
\end{abstract}

Kata Kunci: pekerja miskin, investasi, dana desa

\begin{abstract}
Along with the improvement in the percentage rate of poverty and the unemployment rate at the national level, there is still big homework to be completed regarding the disparity at the regional level. On the one hand, the distribution of unemployment rates by province tends to be equally distributed, while the poverty rate shows the opposite, in which there are still many provinces that have high poverty rates. Those conditions suggests an indication of the working poor problems in Indonesia. This study aims to analyze the phenomenon of working poor and analysis the influence of village fund policy, investment, and employment factors on working poor in 2015-2018. The method of analysis was carried out by using a descriptive analysis and panel data model. The results of the study show that the distribution of the number of working poor by province shows a variety of conditions and tends to be unequal where there are still many regions that have low unemployment rates but the number of working poor tends to be high. The study also found that the village funds program, the percentage of formal workers, and the underemployment rate had a significant effect on the number of working poor.
\end{abstract}

Keyword: working poor, investment, village fund

JEL Classification: H53, O15, 138 


\section{PENDAHULUAN}

Kemiskinan merupakan isu permasalahan ekonomi yang banyak dibahas di Indonesia dan negara berkembang lainnya. Pengentasan kemiskinan selalu menjadi prioritas dalam rangkaian kebijakan ekonomi. Berbagai kajian juga telah dilakukan untuk melihat fenomena kemiskinan di Indonesia baik pada tingkat regional maupun nasional. Sejalan dengan hal tersebut, indikator mengenai kemiskinan menjadi hal yang dasar untuk melihat kemiskinan secara lebih detail dan mendalam. Pada dasarnya indikator kemiskinan telah lama dihasilkan oleh Badan Pusat Statistik dengan menggunakan konsep kemiskinan moneter berdasarkan garis kemiskinan. Data persentase kemiskinan Indonesia terutama pada 2015-2018 menunjukkan adanya trend penurunan yang konsisten. Bahkan, persentase kemiskinan pada tahun 2018 hanya satu digit angka yaitu 9.82 pada semester satu dan 9.66 pada semester dua yang dalam hal ini merupakan persentase kemiskinan terendah sepanjang sejarah Indonesia. Hasil tersebut merupakan pencapaian yang harus disyukuri dan terus ditingkatkan.

Pencapaian terkait penurunan tingkat kemiskinan tidak boleh menjadikan pemerintah lengah terhadap komitmen pengentasan kemiskinan. Sejalan dengan komitmen pengentasan kemiskinan, terdapat banyak aspek yang juga menjadi perhatian dalam rangka pengembangan ekonomi Indonesia secara keseluruhan. Sebagaimana diketahui bahwa pada beberapa tahun ini pemerintah banyak melakukan kebijakan pembangunan ekonomi seperti pembangunan infrastruktur secara masif, pemberian dana desa, serta kebijakan-kebijakan dalam peningkatan investasi. Kebijakan tersebut baik secara langsung maupun tidak langsung akan berdampak pada pasar tenaga kerja. Dampak tersebut dapat terlihat dari indikator tingkat pengangguran terbuka yang cukup terkendali pada kisaran angka 5.5 persen pada periode 2015-2018.
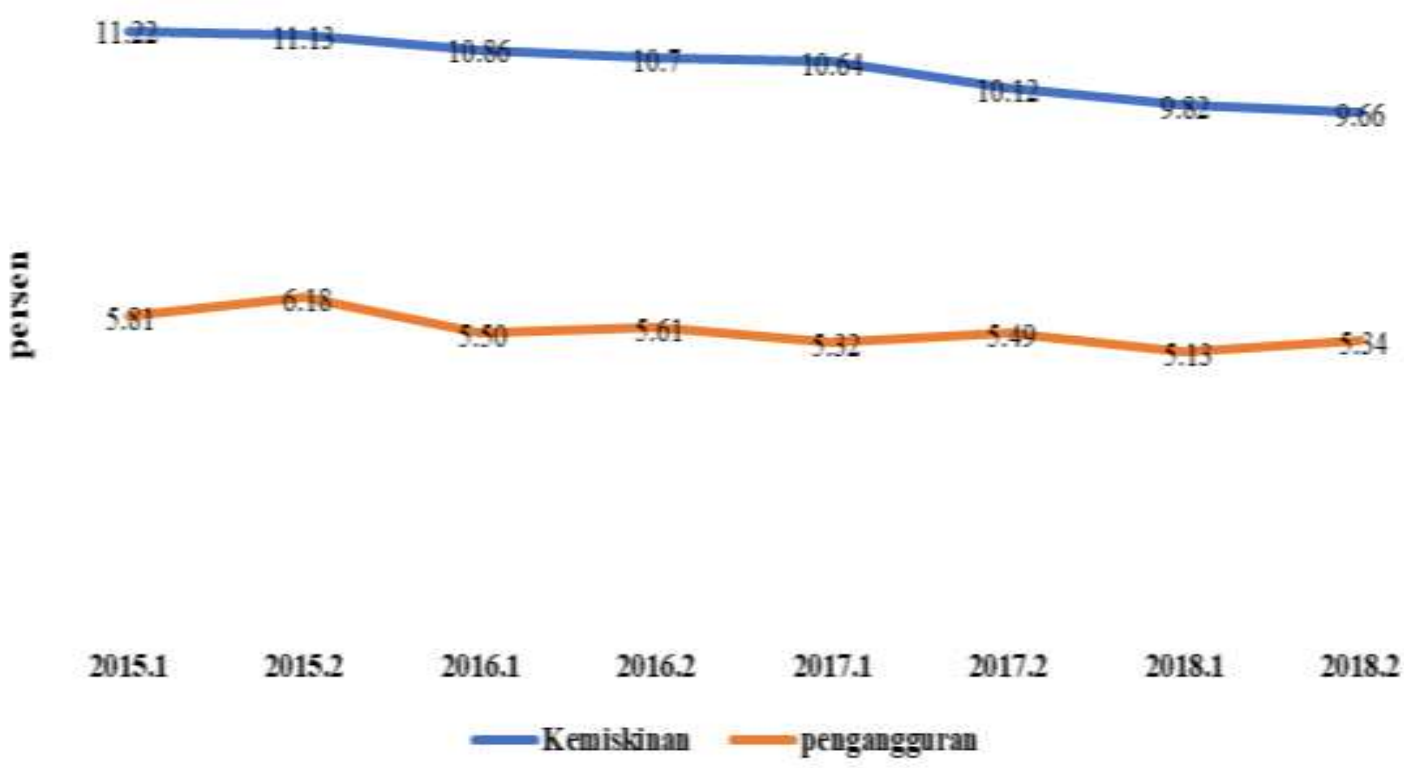

Sumber : Badan Pusat Statistik, diolah

Gambar 1. Persentase Kemiskinan dan Tingkat Pengangguran Terbuka Indonesia tahun 2015-2018

Penurunan tingkat kemiskinan dan positif dalam upaya untuk menurunkan penyerapan tenaga kerja yang optimal menjadi kunci dalam peningkatan kesejahteraan pengangguran dan kemiskinan secara nasional. masyarakat. Gambar 1 menunjukkan hasil yang Namun terdapat fakta lain jika melihat dua indikator tersebut pada tingkat daerah misalnya 
provinsi. Gambar dibawah ini menunjukkan kondisi dari indikator persentase kemiskinan dan indikator tingkat pengangguran terbuka menurut provinsi pada tahun 2018. Tahun 2018 disajikan karena pada tahun ini dua indikator menunjukkan kondisi yang baik jika dilihat secara nasional.

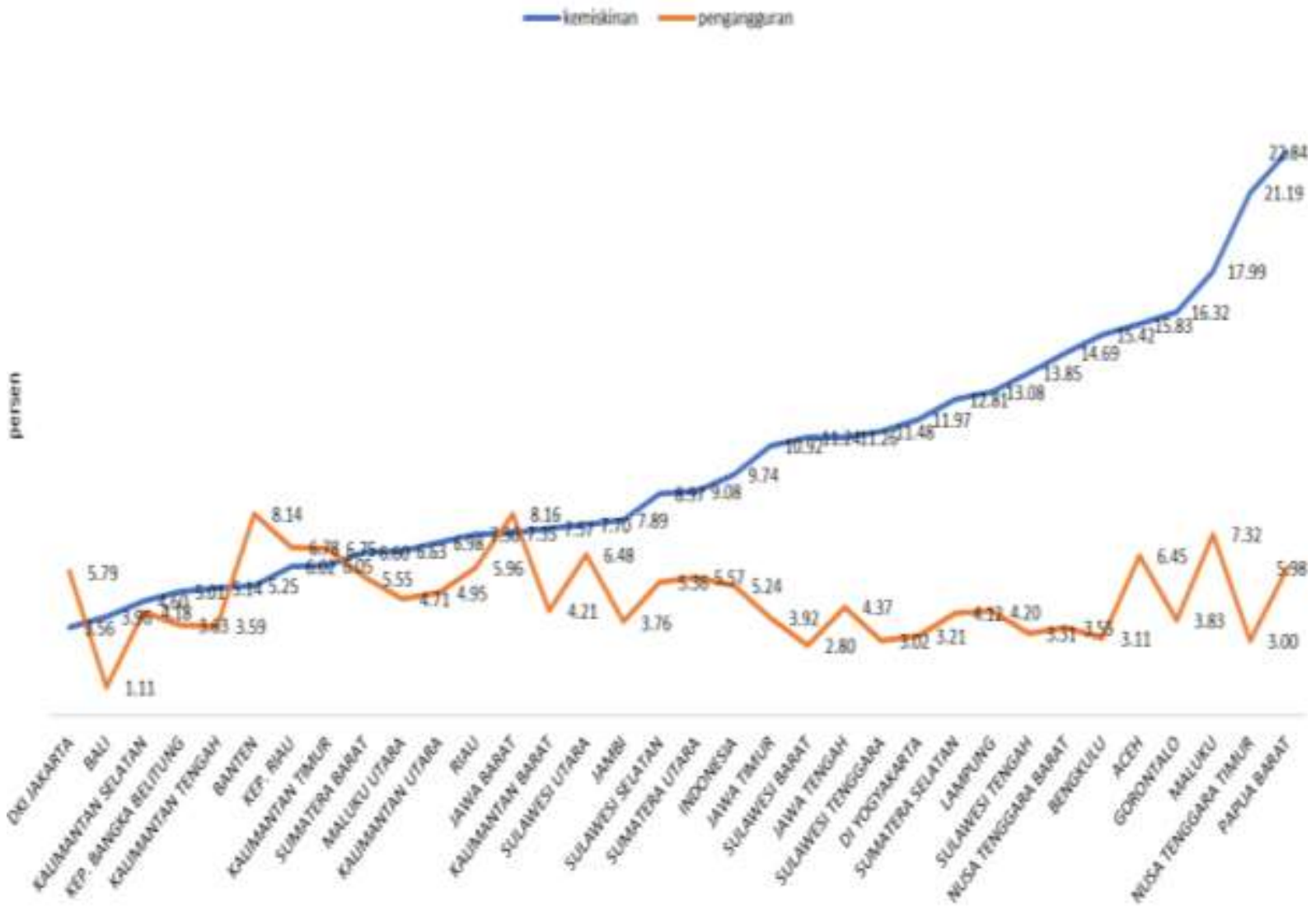

Sumber : Badan Pusat Statistik, diolah

Gambar 2. Persentase Kemiskinan dan Tingkat Pengangguran Terbuka Menurut Provinsi tahun 2018

Pada gambar tersebut, dapat dilihat adanya kondisi yang menarik untuk diperhatikan. Pertama, indikator kemiskinan jika dilihat pada tingkat daerah menunjukkan persebaran cukup beragam antar provinsi. Kondisi tersebut mengindikasikan indikator kemiskinan sudah membaik secara nasional namun masih terdapat gap yang besar jika dilihat menurut provinsi. Disisi lain, indikator pengangguran pada tingkat provinsi menunjukkan persebaran yang cenderung merata. Kedua, dengan melihat kedua indikator secara bersama maka akan terlihat adanya gap yang besar antara kemiskinan dan pengangguran pada hampir setengah dari keseluruhan provinsi. Kondisi ini menarik karena disatu sisi indikator pengangguran baik, namun kemiskinan masih cenderung tinggi. Selanjutnya, kondisi tersebut memunculkan dugaan bahwa masih terdapat atau bahkan banyak tenaga kerja yang meskipun telah berstatus bekerja namun masih dalam kategori miskin. Pada kondisi ini, International Labour Organization (ILO) mengenal istilah working poverty atau working poor yang didefinisikan sebagai empoyed persons living in households in which per-capita 
incomelexpenditure is below the poverty line. Working poor dapat disebut sebagai pekerja miskin yaitu orang-orang yang bekerja namun tidak mendapatkan penghasilan yang cukup untuk mengangkat dirinya dan keluarganya ke atas ambang batas kemiskinan.

Kajian mengenai pekerja miskin masih relatif minim dilakukan di Indonesia. Hal ini dimungkinkan karena belum adanya data yang secara spesifik menunjukkan kondisi pekerja miskin. Padahal, jika dikaji lebih mendalam, fenomena pekerja miskin adalah isu yang cukup penting untuk dasar pengambilan kebijakan baik dari sisi ketenagakerjaan dan dari segi kesejahteraan. Kebijakan baik untuk pengentasan kemiskinan, pembangunan infrastruktur, dan peningkatan investasi seharusnya tidak hanya dapat menyerap tenaga kerja namun lebih jauh lagi harus memastikan bahwa pekerja tersebut mampu hidup layak diatas garis kemiskinan. Untuk itu, dalam penelitian ini terdapat dua tujuan yang akan dibahas yaitu sebagai berikut:

1. Mengetahui gambaran pekerja miskin di Indonesia.

2. Mengetahui pengaruh kebijakan pemerintah baik melalui dana desa, peningkatan investasi, dan faktor ketenagakerjaan lainnya terhadap pekerja miskin di Indonesia.

Adapun penelitian ini dilakukan agar menjadi bahan referensi terhadap kajian mengenai pekerja miskin serta dapat menjadi tambahan informasi mengenai pengaruh kebijakan pemerintah dan faktor ketenagakerjaan terhadap pekerja miskin di Indonesia.

Terdapat beberapa penelitian terdahulu yang membahas mengenai pekerja miskin. Dalam hal pendugaan data pekerja miskin, Majid (2001) memberikan alternatif metode yaitu dengan mengalikan indikator persentase penduduk miskin dengan jumlah tenaga kerja. Dalam penelitiannya, Majid (2001) menggunakan beberapa asumsi yaitu faktor demografi penduduk miskin sama dengan faktor demografi seluruh penduduk dan Tingkat Partisipasi Angkatan Kerja (TPAK) pekerja miskin sama dengan TPAK seluruh pekerja. Selanjutnya, pada tahun 2017 terdapat penelitian dari Sekolah Tinggi Ilmu Statistik (STIS) yang mencoba untuk melakukan pendugaan indikator pekerja miskin secara langsung di Provinsi Bangka Belitung. Metode yang digunakan pada penelitian tersebut adalah estimasi langsung sesuai dengan definisi pekerja miskin. Penelitian tersebut memberikan hasil bahwa angka persentase pekerja miskin sejalan dengan persentase penduduk miskin. Dengan melihat kedua hasil penelitian tersebut, maka pada penelitian ini akan menggunakan metode alternatif sesuai dengan penelitian dari Majid pada tahun 2001 untuk pendugaan indikator pekerja miskin.

Selanjutnya, Penelitian yang dilakukan oleh STIS pada tahun 2017 juga membahas mengenai faktor-faktor yang memengaruhi pekerja miskin di provinsi Bangka Belitung. Penelitian tersebut memberikan kesimpulan bahwa status pekerjaan, sektor lapangan usaha, tingkat pendidikan, lama bekerja, dan upah memberikan pengaruh yang signifikan terhadap persentase pekerja miskin. Jika dilihat dari segi kemiskinan, Hodijah (2017) menyatakan dalam kesimpulan penelitiannya bahwa pertumbuhan ekonomi, Investasi, dan PAD berpengaruh signifikan terhadap kemiskinan di Provinsi Jambi tahun 2001-2015 secara simultan. Dalam beberapa tahun terakhir, berbagai program telah dilaksanakan oleh pemerintah dalam mendorong ekonomi dan ketenagakerjaan baik melalui pembangunan infrastruktur yang masif hingga upaya peningkatan investasi secara berkelanjutan. Peningkatan investasi diduga akan berpengaruh terhadap pasar tenaga kerja dan juga kemiskinan baik secara langsung maupun tidak langsung. Hung (2014) menyatakan dalam penelitiannya bahwa penanaman modal asing berpengaruh terhadap penurunan kemiskinan baik secara langsung maupun tidak langsung di Vietnam pada tahun 1993-2002. Terkait dengan hubungan antara peningkatan investasi dan penurunan kemiskinan, Shamim et al (2014) memberikan rekomendasi kebijakan untuk meningkatkan penanaman modal asing karena terbukti dapat menurunkan tingkat kemiskinan di 
Pakistan pada periode 1973-2011. Dengan melihat hubungan tersebut, adanya peningkatan iklim investasi di Indonesia diharapkan dapat berpengaruh nyata terhadap ketenagakerjaan dan kemiskinan.

Kebijakan pembangunan daerah juga menjadi kebijakan yang masif dilakukan salah satunya melalui dana desa. Kebijakan dana desa pada dasarnya bertujuan untuk mengembangkan perekonomian desa dimana pengentasan kemiskinan juga menjadi salah satu bagiannya. Terkait dengan peran dana desa terhadap pengentasan kemiskinan, terdapat beberapa hasil penelitian yang berbeda. Lalira D et al (2018) memberikan kesimpulan bahwa dana desa tidak berpengaruh signifikan terhadap tingkat kemiskinan di Kabupaten Talaud periode 20152017. Hasil lain diperoleh oleh Sari dan Abdullah (2017) yang menyatakan bahwa dana desa berpengaruh signifikan dalam penurunan kemiskinan di 13 desa di Kabupaten Tulungagung tahun 2015-2016. Dengan melihat hasil yang beragam mengenai pengaruh dana desa terhadap kemiskinan, maka peneliti juga tertarik untuk melihat bagaimana pengaruh dana desa terutama pada tingkat nasional. Selanjutnya, dinamika sektor ketenagakerjaan juga diduga berpengaruh terhadap kesejahteraan pekerja. Salah satu contohnya ada sektor formal-informal yang dapat memengaruhi tingkat kesejahteraan. Taufiq (2017) menyatakan bahwa kepala rumah tangga yang selalu bekerja di sektor informal memiliki peluang yang lebih besar untuk mengalami insiden kemiskinan baik kronis maupun sementara. Berdasarkan penelitian-penelitian terdahulu, maka peneliti tertarik untuk melihat fenomena pekerja miskin serta peran dari kebijakan pemerintah maupun kondisi ketenagakerjaan terhadap pekerja miskin di Indonesia.

\section{METODE}

\section{Jenis dan Sumber Data}

Pada penelitian ini, data yang digunakan adalah data sekunder dengan unit observasi adalah provinsi di Indonesia pada periode 2015-2018.
Data variabel yang akan digunakan adalah sebagai berikut:

1. Persentase pekerja miskin provinsi tahun 20152018

Data persentase pekerja miskin merupakan data turunan yang berasal dari perhitungan berdasarkan data persentase penduduk miskin dan tenaga kerja. Definisi pekerja miskin yang digunakan yaitu orang-orang yang bekerja namun tidak mendapatkan penghasilan yang cukup untuk mengangkat dirinya dan keluarganya ke atas ambang batas kemiskinan. Perhitungan data pekerja miskin berdasarkan pada penelitian Majid pada tahun 2001. Selanjutnya, data persentase kemiskinan merupakan persentase penduduk miskin berdasarkan garis kemiskinan yang dihitung oleh Badan Pusat Statistik. Data yang digunakan adalah data tahunan dengan mengambil rata-rata dari 2 semester setiap tahunnya dan satuannya adalah persen. Sumber data berasal dari Badan Pusat Statistik.

2. Realisasi Investasi Provinsi tahun 2015-2018

Data realisasi investasi merupakan data penjumlahan dari realiasi Penanaman Modal Asing (PMA) dan Penanaman Modal Dalam Negeri (PMDN). Satuan yang digunakan adalah Miliar Rupiah dengan konversi menggunakan nilai tukar tengah untuk mengubah satuan dari PMA. Sumber data berasal dari publikasi Badan Koordinasi Penanaman Modal dan Badan Pusat Statistik.

3. Anggaran Dana Desa tahun 2015-2018

Anggaran dana desa pada tingkat provinsi diperoleh dari penjumlahan dana desa kabupaten pada masing-masing provinsi. Satuan yang digunakan adalah ribu rupiah serta data berasal dari website Kementrian Keuangan.

4. Persentase Pekerja Formal Provinsi tahun 20152018

Pekerja formal adalah pekerja yang memiliki status pekerjaan sebagai berusaha sendiri dibantu buruh tetap/dibayar dan buruh/ karyawan/pegawai. Definisi tersebut diperoleh berdasarkan laporan publikasi dari Badan Pusat 
Statistik. Satuan yang digunakan adalah persentase dan sumber data berasal dari Badan Pusat Statistik.

5. Persentase Tingkat Setengah Pengangguran Provinsi tahun 2015-2018

Indikator setengah pengangguran merupakan pekerja yang memiliki jam kerja dibawah jam kerja normal yaitu 35 jam. Data ini memiliki satuan persen dan bersumber dari Badan Pusat Statistik.

\section{Metode Analisis}

Penelitian ini akan menggunakan dua metode untuk menjawab tujuan penelitian. Metode yang pertama adalah analisis deskriptif dengan menggunakan grafik sedangkan metode yang kedua adalah analisis inferensia dengan menggunakan regresi data panel. Analisis regresi data panel pada penelitian ini hanya mencangkup 33 provinsi dengan tidak memasukkan Provinsi DKI Jakarta karena tidak mendapatkan anggaran dana desa. Adapun secara ringkas prosedur analisis regresi data panel meliputi pemilihan model yang tepat, pengujian asumsi klasik, dan dilanjutkan dengan analisis. Adapun spesifikasi model yang diajukan dalam penelitian ini adalah sebagai berikut:

$$
\begin{aligned}
W P r_{i t}= & \beta_{0}+\beta_{1} \operatorname{Ln}(\operatorname{Inv})_{i t}+\beta_{2} \operatorname{Ln}(D D)_{i t} \\
& +\beta_{3} \text { FORMAL }_{i t}+\beta_{1} \operatorname{TSP}_{i t}+\varepsilon_{i t}
\end{aligned}
$$

keterangan :

$\begin{array}{ll}\text { Ln } & \text { : Logaritma natural } \\ \text { WPr } & \begin{array}{l}\text { : Working Poor Rate atau persentase } \\ \text { pekerja miskin (persen) }\end{array} \\ \text { Inv } & : \text { Realisasi Investasi (miliar rupiah) } \\ \text { DD } & : \text { Anggaran dana desa (ribu rupiah) } \\ \text { Formal } & : \text { Persentase pekerja formal (persen) } \\ \text { TSP } & : \text { Tingkat setengah pengangguran } \\ & \text { (persen) } \\ \text { i } & : 1,2, \ldots, 33 \\ \mathrm{t} & : 1,2,3,4\end{array}$

\section{HASIL DAN PEMBAHASAN}

\section{Analisis Deskriptif}

Kajian mengenai pekerja miskin masih cukup sedikit dibahas untuk wilayah Indonesia. Hal ini dapat dipahami mengingat belum tersedianya data yang secara khusus mengukur mengenai pekerja miskin. Ketenagakerjaan dan kemiskinan merupakan isu yang banyak dan selalu dibahas mengingat dua hal tersebut masih menjadi masalah bagi Indonesia. Kedua aspek tersebut sebenarnya tidak bisa hanya dilihat sebagai satu aspek yang berdiri sendiri, tetapi harus dilihat sebagai satu kesatuan yang saling terkait. Hal ini dimaksudkan agar tidak terjadi bias dalam melihat fenomena yang ada. Contoh kasusnya ketika kita melihat bahwa suatu daerah yang memiliki angka pengangguran rendah tetapi kemiskinan masih cukup tinggi dimana ketika hanya melihat angka pengangguran maka tidak terjadi masalah sedangkan disisi lain kemiskinan masih tinggi. Pada kasus tersebut maka ada indikasi bahwa masih banyak tenaga kerja yang walaupun sudah bekerja tetapi masih berada dalam kemiskinan. Fenomena tersebut sebaiknya juga diperhatikan terutama untuk arah kebijakan yang lebih tepat sasaran.

Pada penelitian ini, data pekerja miskin diperoleh dari pengolahan data kemiskinan dan tenaga kerja. Pada aspek ketenagakerjaan, penyerapan angkatan kerja menjadi hal yang penting agar dapat menekan angka pengangguran. Tenaga kerja yang bekerja diharapkan mampu memenuhi kebutuhan hidupnya dan terbebas dari jurang kemiskinan. Jika melihat angka pengangguran nasional, Indonesia memiliki trend yang cukup baik dengan rata-rata 5.5 persen selama kurun 2015-2018 dan cenderung merata pada semua provinsi seperti yang terlihat pada Gambar 3. 
Disisi lain, kondisi pekerja miskin masih menunjukkan hasil yang patut diperhatikan. Pada gambar tersebut, terlihat bahwa persentase pekerja miskin belum merata dimana masih banyak daerah yang memiliki angka pekerja miskin tinggi meskipun penganggurannya rendah.
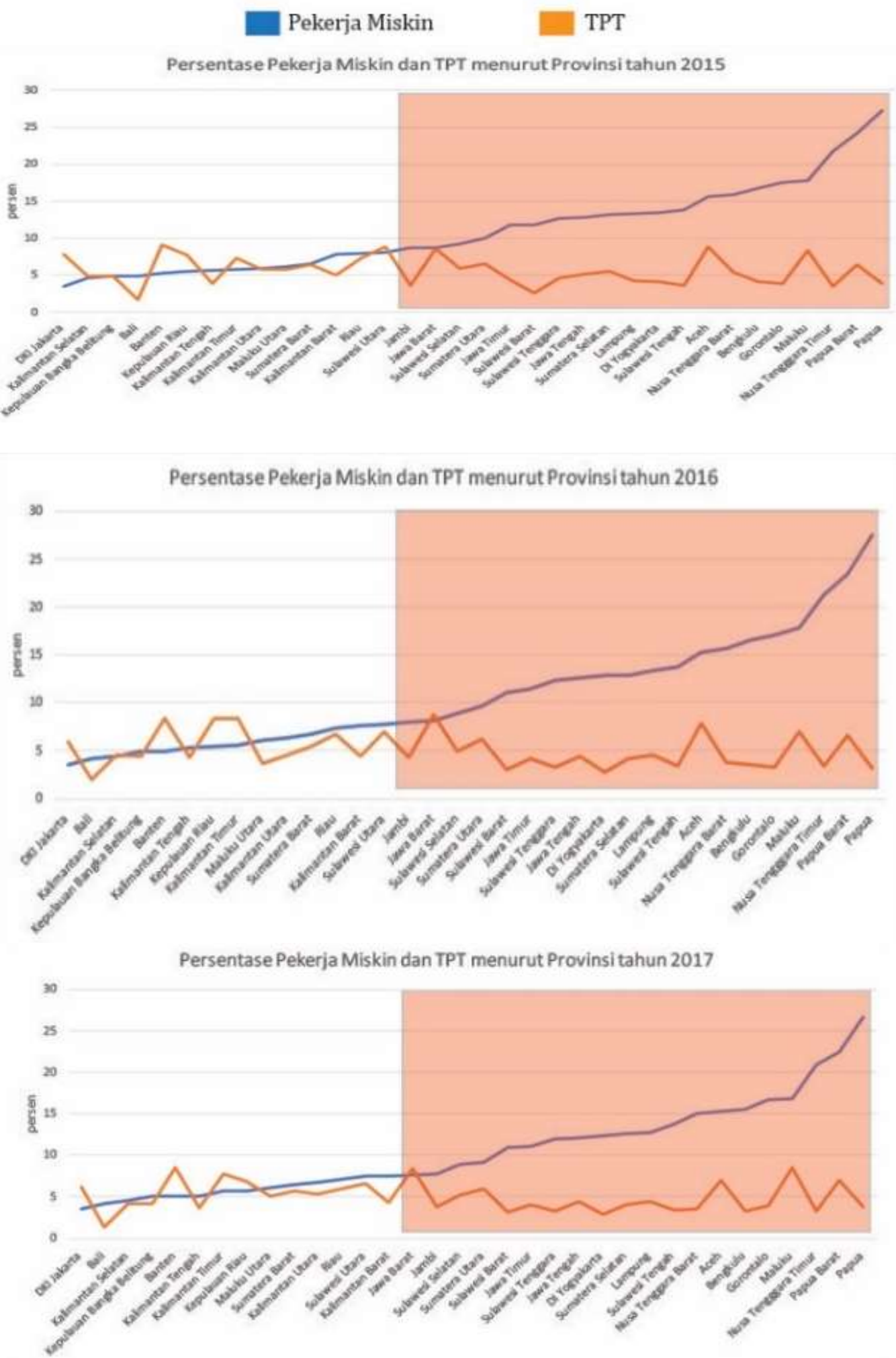


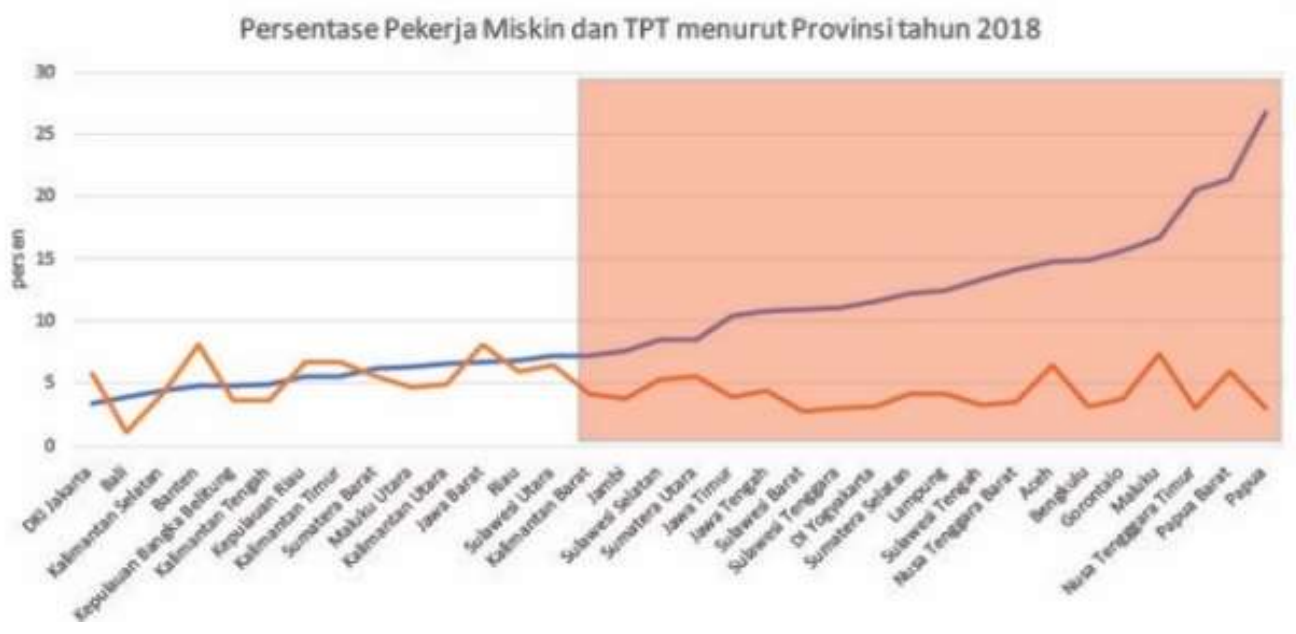

Sumber : Badan Pusat Statistik, diolah

Gambar 3. Persentase Pekerja Miskin dan Tingkat Pengangguran Terbuka Provinsi tahun 2015-2018.

Pada gambar tersebut terlihat bahwa sebaran angka persentase pekerja miskin pada tingkat provinsi memiliki nilai yang beragam. Jika melihat kondisi pada 2015 sampai 2018, belum ada perbedaan yang signifikan dalam perubahan pola sebaran pekerja miskin. Pada gambar tersebut terlihat bahwa terdapat daerah yang memilki angka pengangguran rendah tetapi memiliki angka pekerja miskin yang tinggi. Hal ini harus menjadi perhatian bahwa terdapat hal yang tidak kalah penting disamping penyerapan tenaga kerja yaitu bagaimana meningkatkan kesejahteraan dari pekerja.
Pemerintah tentunya terus berupaya dalam pengentasan kemiskinan melalui berbagai macam kebijakan. Strategi kebijakan membangun Indonesia melalui desa menjadi hal yang positif yaitu dengan kebijakan dana desa. Pengalokasian dana desa diharapkan berfokus pada pengentasan kemiskinan serta mengatasi ketimpangan antar desa. Jika dikaitkan dengan indikator pekerja miskin Indonesia pada tahun 2015-2018, terdapat indikasi adanya kesesuaian antara peningkatan dana desa dengan penurunan tingkat persentase pekerja miskin seperti terlihat pada Gambar 4.

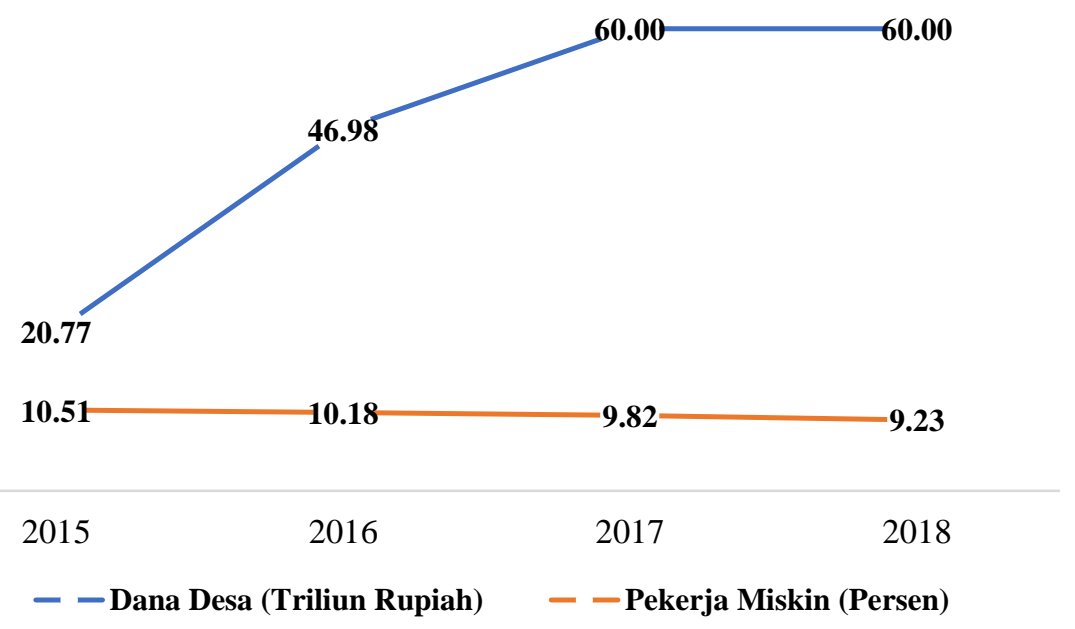

Sumber : Badan Pusat Statistik, diolah

Gambar 4. Persentase Pekerja Miskin dan Total Dana Desa Indonesia tahun 2015-2018 
Pada Gambar 4 terlihat adanya indikasi hubungan negatif antara dana desa dengan persentase pekerja miskin. Pada tahun 20152018, dana desa secara nasional menunjukkan kenaikan yang konsisten. Sejalan dengan itu, persentase pekerja miskin menunjukkan penurunan yang konsisten juga. Indikasi hubungan negatif ini juga didukung dengan besarnya koefisien korelasi antara keduanya yaitu sebesar -0.84. Dengan melihat sebaran data tersebut, maka kebijakan pembangunan desa dapat menjadi perhatian bagi pemerintah kedepan.

\section{Analisis Inferensia}

Analisis selanjutnya bertujuan untuk melihat pengaruh dari variabel bebas terhadap variabel terkait yaitu persentase pekerja miskin dengan menggunakan regresi data panel sebagai alat analisisnya. Model terbaik yang diperoleh adalah Fixed effect Cross-section SUR (PCSE) dengan hasil sebagai berikut.

Tabel 1. Hasil Regresi Data Panel

\begin{tabular}{lrrr}
\hline \multicolumn{1}{c}{ Variabel } & Koefisien & t-Statistic & Prob. \\
C & 23.18613 & 11.17933 & 0.0000 \\
LOG(INVESTASI) & 0.065867 & 1.926255 & 0.0571 \\
LOG(DD) & $\mathbf{- 0 . 6 0 5 5 5 8}$ & -7.298639 & 0.0000 \\
FORMAL & $\mathbf{- 0 . 0 2 0 2 3 6}$ & -3.521447 & 0.0007 \\
TSPT & $\mathbf{0 . 0 5 1 4 4 6}$ & 2.796955 & 0.0062 \\
\hline
\end{tabular}

Adjusted R-squared

0.997602

$\operatorname{Prob}($ F-statistic) Sumber : Eviews 9, diolah

Hasil pada tabel tersebut merupakan hasil regresi final yang telah memenuhi asumsi klasik yaitu normalitas dan nonmultikolinieritas. Berdasarkan hasil tersebut, terlihat bahwa secara simultan variabel-variabel bebas berpengaruh signifikan terhadap persentase pekerja miskin. Besarnya koefisien determinasi juga cukup tinggi yaitu sebesar 99 persen yang artinya variasi variabel bebas yang dimasukkan dalam model sudah cukup baik menjelaskan variasi variabel terkait yaitu persentase pekerja miskin. Adapun secara parsial, hanya variabel investasi swasta saja yang tidak signifikan sedangkan tiga variabel lain signifikan pada tingkat signifikansi 1 persen. Adapun analisis pengaruh dari variabel bebas terhadap variabel terikat adalah sebagai berikut. a. Pengaruh investasi terhadap pekerja miskin

Berdasarkan hasil yang diperoleh pada model, investasi tidak berpengaruh signifikan terhadap pekerja miskin. Investasi pada penelitian ini merupakan penjumlahan dari Penanaman Modal Asing dan Penanaman Modal Dalam Negeri. Hasil ini menjadi indikasi bahwa investasi baik dari dalam maupun asing belum mampu menurunkan tingkat persentase pekerja miskin. Untuk melihat penyebab dari pengaruh yang tidak signifikan ini harus diteliti lebih jauh dan lebih mendetail. Namun, hasil ini harus menjadi perhatian mengingat kebijakan ekonomi seperti pembangunan infrastruktur, reformasi birokrasi dalam dunia usaha, dan lain-lain memang ditujukan untuk 
pengembangan ekonomi salah satunya adalah memacu tingkat investasi baik dari dalam maupun luar negeri. Investasi seharusnya mampu menyerap tenaga kerja utamanya tenaga kerja yang masih miskin. Investasi seharusnya bisa lebih tepat sasaran meningkatkan kesejateraan utamanya yang masih hidup dibawah garis kemiskinan.

b. Pengaruh dana desa terhadap pekerja miskin.

Peran pemerintah juga harus menjadi perhatian dalam rangka membangun perekonomian. Salah satu kebijakan yang secara langsung ditujukan untuk pembangunan adalah kebijakan dana desa. Kebijakan dana desa secara khusus bertujuan untuk membangun perekonomian desa dan juga dalam rangka pengentasan kemiskinan. Pada penelitian ini, diperoleh hasil bahwa variabel dana desa berpengaruh signifikan terhadap pekerja miskin dengan koefisien sebesar -0.605. Hasil tersebut berarti bahwa pada periode 2015-2018, dana desa secara signifikan mampu menurunkan pekerja miskin. Besarnya koefisien regresi yang diperoleh dapat diartikan bahwa setiap kenaikan 1 persen dana desa maka akan menurunkan persentase pekerja miskin sebesar 0.6 persen. koefisien yang diperoleh merupakan yang terbesar diantara variabel yang lain. Dengan melihat hasil ini, maka dapat disimpulkan bahwa dana desa cukup efektif dalam peningkatan kesejahteraan pekerja miskin.

Pembangunan desa melalui penggunaan dana desa yang tepat sasaran menjadi kunci dalam upaya pengentasan kemiskinan utamanya melalui sektor ketenagakerjaan. Pengembangan ekonomi desa berbasis padat karya harus terus dilaksanakan sesuai dengan tujuan dari kebijakan dana desa. Hal ini didukung dengan data dari Kementrian Desa, Pembangunan Daerah Tertinggal dan Transmigrasi Republik Indonesia yang menyebutkan bahwa kontribusi dana desa dalam penyerapan tenaga kerja pada tahun 2017 mengalami peningkatan sampai 3 kali lipat. Tenaga kerja yang terserap dari kontribusi dana desa mencapai 1.7 juta jiwa pada 2015, meningkat menjadi 5 juta jiwa pada tahun 2017. Selanjutnya, dana desa yang disalurkan ke desa-desa dimanfaatkan untuk membangun infrastruktur penunjang kegiatan di desa seperti BUMDesa, pasar desa, PAUD, dan POLINDES. Pembangunan infrastruktur tersebut diharapkan mampu meningkatkan perekonomian di desa-desa.

Pengaruh dari dana desa menjadi indikasi bahwa pembangunan melalui desa merupakan langkah yang baik untuk membangun dasar ekonomi yang lebih kuat. Seperti diketahui bahwa kemiskinan di desa cenderung lebih tinggi dibandingkan daerah perkotaan. Pada periode 2015-2018, kemiskinan daerah pedesaan memiliki rata-rata 13.75 persen sedangkan pada daerah perkotaan sebesar 7.61 persen. Sejalan dengan hal tersebut, penelitian dari STIS pada tahun 2017 juga menyebutkan bahwa pekerja yang tinggal di desa memiliki rata-rata kecenderungan lebih besar untuk miskin dibandingkan pekerja yang tinggal di kota. Dengan melihat kondisi ini, maka pemerintah perlu menjaga paradigma pembangunan desa dengan alokasi dana yang konsisten serta tepat sasaran. Namun, seperti fokus pada penelitian ini yaitu kebijakan pemerintah diharapkan tidak hanya berfokus pada penyerapan tenaga kerja atau mengurangi pengangguran tetapi harus juga mampu menciptakan lapangan kerja yang ideal bagi kesejahteraan pekerja.

c. Pengaruh persentase pekerja formal terhadap pekerja miskin

Pada penelitian ini faktor pekerja formal dimasukkan untuk melihat bagaiamana sektor formal informal mampu menjadi faktor penurun pekerja miskin. Data BPS membedakan pekerja formal berdasarkan status pekerjaan dimana status berusaha sendiri dibantu buruh tetap dan pegawai/karyawan/buruh merupakan pekerja formal. Dalam memahami kategori ini, pekerja formal dianggap lebih memiliki faktor kepastian dibandingkan pekerja informal. Selain itu, pada publikasi mengenai ekonomi 
informal di Idonesia pada tahun 2010, ILO menyebutkan bahwa korelasi antara kemiskinan dan pekerja informal di Indonesia pada tahun 2009 ternyata cukup moderat yaitu 0.572. Selain itu, harus disadari bahwa relasi antara kemiskinan dan pasar tenaga kerja informal memilik relasi berupa terciptanya sebuah lingkaran setan utamanya bagi masyarakat miskin yang tidak memiliki keterampilan bekerja di sektor formal.

Berdasarkan hasil model seperti pada Tabel 1, diperoleh informasi bahwa persentase pekerja formal berpengaruh signifikan terhadap persentase pekerja miskin dengan koefisien sebesar -0.02. Hasil tersebut dapat diartikan bahwa kenaikan persentase pekerja formal sebesar 1 persen akan menyebabkan pekerja miskin turun sebesar 0.02 persen. Hubungan negatif tersebut juga memiliki indikasi bahwa kenaikan pada persentase pekerja formal merupakan hal yang positif. Meskipun secara lebih detail belum bisa dijelaskan dalam penelitian ini, namun hal ini sejalan dengan hasil yang dipublikasikan oleh ILO pada tahun 2010 tentang ekonomi informal di Indonesia. Selain itu, ketika dicermati kembali bahwa pekerja formal dapat berstatus sebagai berusaha sendiri dibantu buruh tetap yang artinya bahwa peluang untuk meningkatkan kemampuan enterpreunership menjadi hal yang bagus untuk dikembangkan. Sehingga, kebijakan untuk mengembangkan keterampilan serta peningkatan daya dukung terhadap kewirausahaan menjadi penting untuk diperhatikan sehingga tidak hanya dapat mengurangi pengangguran namun lebih jauh lagi dapat meningkatkan kesejahteraan pekerja.

d. Pengaruh tingkat setengah pengangguran terhadap pekerja miskin

Pada analisis sebelumnya, telah diperoleh informasi bahwa persebaran pekerja miskin menurut provinsi memiliki nilai yang beragam. Disisi lain, angka pengangguran cenderung merata yang dapat diartikan bahwa terdapat banyak pekerja miskin. Dari dua informasi tersebut, muncul sebuah pertanyaan apakah terdapat faktor lain selain pengangguran yang harus diperhatikan untuk memahami fenomena pekerja miskin sehingga pada penelitian ini memasukkan variabel tingkat setengah pengangguran. Secara konsepsi setengah penganggur berhubungan erat dengan jam kerja dan ini diduga relevan dengan penghasilan pekerja miskin.

Berdasarkan hasil pada model, diperoleh informasi bahwa tingkat setengah pengangguran berpengaruh signifikan terhadap persentase pekerja miskin dengan koefisien sebesar 0.051. Pengaruh positif tersebut memberikan indikasi bahwa semakin banyak pekerja yang memiliki jam kerja dibawah normal memiliki dampak terhadap peningkatan persentase pekerja miskin. Hasil tersebut juga dapat diartikan bahwa terdapat faktor lain yang harus oleh pemerintah selain tingkat pengangguran karena terdapat indikator lain yang berpengaruh positif terhadap pekerja miskin yaitu tingkat setengah pengangguran.

\section{KESIMPULAN DAN SARAN}

\section{Kesimpulan}

Berdasarkan hasil dan pembahasan yang telah dijelaskan pada bagian sebelumnya, maka terdapat beberapa poin kesimpulan yang dapat dihasilkan yaitu sebagai berikut:

1. Persebaran angka pekerja miskin menurut provinsi menunjukkan kondisi yang beragam dan cenderung tidak merata. Pada tahun 20152018 belum terlihat adanya perubahan pola persebaran dimana masih banyak daerah yang memiliki angka pengangguran rendah tetapi angka pekerja miskinnya cenderung tinggi.

2. Berdasarkan model yang dihasilkan, terdapat tiga variabel yang berpengaruh signifikan terhadap persentase pekerja miskin yaitu anggaran dana desa, persentase pekerja formal, dan tingkat setengah pengangguran. Disisi lain, realisasi investasi tidak berpengaruh signifikan terhadap persentase pekerja miskin. Anggaran dana desa dan 
persentase pekerja formal memiliki hubungan yang negatif yang berimplikasi pada penurunan persentase perkeja miskin sedangkan tingkat setengah pengangguran berhubungan positif yang berimplikasi pada penambahan persentase pekerja miskin. Hasil pada model memberikan indikasi bahwa pembangunan desa lebih efektif mengurangi persentase pekerja miskin. Selanjutnya, semakin banyak pekerja yang berada di sektor formal juga dapat menurunkan persentase pekerja miskin. Dalam hal jam kerja, semakin banyak pekerja yang bekerja dibawah jam kerja normal dapat meningkatkan persentase pekerja miskin.

\section{Saran}

Berdasarkan hasil pada penelitian ini, terdapat informasi yang bisa menjadi bahan referensi terhadap kebijakan kedepan terutama kebijakan berbasis wilayah yaitu pada unit provinsi. Pertama, fenomena pekerja miskin harus menjadi perhatian dalam melihat aspek ketenagakerjaan dan kemiskinan. Kedua, kebijakan pemerintah terkait pembangunan ekonomi terutama peningkatan investasi swasta baik dari dalam maupun luar negeri harus lebih dioptimalkan agar dapat meningkatkan kesejahteraan masyarakat. Ketiga, paradigma pembangunan ekonomi desa harus dipertahankan karena dapat secara langsung berpengaruh terhadap pekerja di desa. Kebijakan dana desa dengan mengutamakan kegiatan ekonomi padat karya dapat lebih dioptimalkan. Selanjutnya, penciptaan lapangan kerja yang layak juga perlu ditingkatkan sehingga dapat meningkatkan faktor kepastian kepada tenaga kerja.

\section{DAFTAR PUSTAKA}

Badan Pusat Statistik. (Berbagai Tahun). Keadaan Angkatan Kerja Indonesia. Jakarta: Badan Pusat Statistik.

Badan Pusat Statistik. (Berbagai Tahun). Penanaman Modal Dalam Negeri. Jakarta: Badan Pusat Statistik.
Badan Pusat Statistik. (Berbagai Tahun). Penanaman Modal Luar Negeri. Jakarta: Badan Pusat Statistik.

Carr M, Chen M A. 2001. Globalization and The Informal Economy: How Global Trade and Investment Impact on the Working Poor. WIEGO.

Hodijah, Siti. 2017. Pengaruh Pertumbuhan Ekonomi, Investasi, PAD terhadap Kemiskinan Melalui Kesempatan Kerja di Provinsi Jambi. Jurnal Ekonomi dan Kebijakan Publik Indonesia. Vol. 4 No.2

Hung, Trang Tong. 2014. Impacts of Foreign Direct Investment on Poverty Reduction in Vietnam. IDS Program. GRIPS.

ILOSTAT. 2019. The Working Poor or How a Job is no Guarantee of Decent Living Conditions. Spotlight on Work Statistics.

Lalira D, Nakoko A, Pingkan I. 2018. Pengaruh Dana Desa dan Alokasi Dana Desa terhadap Tingkat Kemiskinan di Kecamatan Gemeh Kabupaten Kepulauan Talaud. Jurnal Berkala Ilmiah Efisiensi. Vol, 8 No. 14.

Majid, N. 2001. The Size of The Working Poor Population in Developing Countries. Employment Paper.

Momongan, J. E. 2013. Investasi PMA dan PMDN Pengaruhnya terhadap Perkembangan PDRB dan Penyerapan Tenaga Kerja serta Penanggulangan Kemiskinan di Sulawesi Utara. Jurnal EMBA. 1(3):530-539.

Sabiq M. 2017. Dana Desa, Lapangan Kerja, dan Kemiskinan [Internet]. Jakarta (ID): Kementrian Desa, Pembangunan Daerah Tertinggal dan Transmigrasi Republik Indonesia. [dilihat 9 Oktober 2019].

Sari M, Abdullah F. 2017. Analisis Ekonomi Kebijakan Dana Desa terhadap Kemiskinan Desa di Kabupaten Tulungagung. Jurnal Ekonomi Pembangunan. Vol. 15. No. 1.

STIS. 2017. Pekerja Miskin di Provinsi Kepulauan Bangka Belitung tahun 2017. PKL STIS 2017. 
Susilowati N I, Susilowati D, Hadi S. 2017. Pengaruh Alokasi Dana Desa, Dana Desa, Belanja Modal, dan Produk Domestik Regional Bruto terhadap Kemiskinan Kabupaten/Kota di Jawa Timur. Jurnal Ilmu Ekonomi. 1(4):514-526.

Shamim A, Azeem P, Muddassir S. 2014. Impact of Foreign Direct Investment on Poverty
Reduction in Pakistan. International Journal of Academic Research in Business and Social Sciences. Vol. 4 No. 10.

Taufiq, Nuri. 2017. Pengaruh Dinamika Sektor Pekerjaan terhadap Dinamika Kemiskinan di Indonesia. SOSIO KONSEPSIA. Vol. 7 No. 1. 